\title{
Gender Issue in Transportation Sector of Nigeria: A Case Study of Lokoja, Kogi State
}

\author{
Shaibu Hasssan Richard ${ }^{1} \&$ Emmanuel Okokondem Okon ${ }^{1}$
}

${ }^{1}$ Department of Economics, Kogi State University, Anyigba, Kogi State, Nigeria. Correspondence: Shaibu Hasssan Richard, Department of Economics, Kogi State University, Anyigba, Kogi State, Nigeria. E-mail: richshaha@yahoo.com. Tel: +2347034504427

Received: January 11, 2018

Accepted: January 14, 2018

Online Published: January 21, 2018

\begin{abstract}
This paper aimed at finding out what constraint women in transport sector in Lokoja and why employers are reluctant in employing women in the sector? The null hypothesis is that women constraints have no significant effect in transportation sector in Lokoja. Information for the paper was basically from the questionnaire survey method Data generated were analyzed using descriptive statistics such as mean, simple percentages and graphical illustrations. Chi-square analysis was used to test the formulated hypothesis. The result reveals that women constraints have significant effect in transportation sector in Lokoja. Transport business in Lokoja is so dominated by male counterpart and yet some routes are not adequately covered. Based on the aforementioned findings, it is recommended that social attitude in Lokoja, Kogi state and Nigeria in general should be changed in favour of women employment in transport sector. The government of Kogi state should establish driving schools and transport scheme meant to enhance the livelihood of women. The National Union of Road Transport Worker (NURTW) should encourage women to invest in the sector.
\end{abstract}

Keywords: Gender bias, transport sector, Lokoja, labour force, Nigeria.

\section{Introduction}

Gender bias in transportation sector is a matter of concern for any welfare democratic and developing state. Equal opportunities and compensation of female work force are required to be built in governmental policies of such state. For this reason, there are agitations across the globe focusing on the empowerment and right of women in all aspect including transportation sector, employment and economic participation with a view to reduce gender inequality (Bivas \& Panigrahi, 2013). Transport is one of several sectors that have traditionally been regarded as 'no place for women in all respects and in many countries, this is still the case today. Detailed and accurate statistics on the employment of women in the transport sector are hard to come by, especially for specific transport modes such as maritime, ports, inland waterways, civil aviation, road and railways (Peter, 2013). Sustainable transport cannot be said to be achieved if it is not coupled with effective and efficient programs that enhances livelihood of people especially women (Odufuwa, 2007).

In most developing countries like Nigeria, gender dimensions in transportation planning, management and employment have been one of the least considered aspects in transportation and development (Odufuwa, 2007). The problem manifest in countless cities in Nigeria shows that most cities with regards to public transportation offer little or no perspective for women (Fernando, 2002; World Bank, 2001; \& TRB, 2006).

The primary goal for national policy maker is to raise the level of women welfare and employment in transportation sector within the nations. The state of transportation in Nigeria can be classified into five major modes- roads, rail, water, air and pipelines, the contribution of the transport sector to the economy of Nigeria if considered tend to stagnate or decline at about 3\% of GDP (Ogunsanya, 2002). Road in particular decline from 5.17\% in 1981, 2.90\% in 1995 and $2.8 \%$ in 1996 and $2.84 \%$ in 1997 and less than $2.5 \%$ in recent time (Odufuwa, 2007).

Indeed transport planner and policy makers all over the world have increasingly recognized the fact that, the difference between the travel and employment pattern between men and women are central and reoccurring features 
in transportation sector all over the world (Peter, 2002). Despite improvement in building women capacities, gender gap, inefficient means of employment and travel continue to persist (Oyesiku \& Odufuwa, 2002; Asiyanbola, 2007).

\section{Research Problem}

The transport sector in Lokoja appears to be characterized by gender bias, which results in an unequal treatment of women in relations to their access to employment, professional training and working conditions. Less attention is been given to this issue due to poor institution established in enlightening the public about the importance of women employment and empowerment in the transportation sector, lack of policy made by government and social partner in protecting women against all form of criminal activities including harassment, sexual assault and loss of property. Despite the noble goal of preventing discrimination on the bases of sex, women continue to face disadvantage compared to the male counterpart, who enjoys greater opportunities in the transportation sector in Lokoja.

3. Research Questions

This paper attempts to answer the following questions:

- What are the constraints faced by women in transportation sector in Lokoja?

- Why are employers reluctant in employing women in transportation sector in Lokoja?

4. Research Hypotheses

For the purpose of this study, the following hypothesis was formulated:

$\mathrm{H}_{0}$ : Women constraints have no significant effect in transportation sector in Lokoja.

5. Review of Literature

The growing emphasis on promoting sustainable means of transport, to enhanced livelihoods of women has over the year's motivated conversation among scholars in different fields (Odega, 2014; Haralambos and Holborn, 2007; Hara, 2013; Jhingan, 2007; and Oladele, 2001).The issue has yielded extensive literature discussing different aspects of gender and transport in most countries (Srinivasan, 2005; Rosenbloom, 2005; Anand and Tiwari, 2006; Kamuhanda and Schmidt, 2009; and Hanson and Hanson, 1980).

In Nigeria, Adetunji (2013) used a sample size of 11 to assess the quality of urban transport services. The findings revealed that some of the urban residents who are less accessible to transport services in their neighborhood commute on foot to meet their travel demands. Odufuwa, Oriole, \& Otubaga (2012) used a propulsive sampling technique to administered 203 questionnaires to examine women and the use of public transport in Nigeria traditional city-Ibadan. It findings reveal that, public transport system in the city is inefficient. Bivas \& Panigrahi (2013) used an annual survey of industry (ASI) to find out gender issues in term of female workforce participation and wage differentials the organized manufacture sector in Indian, and find out that there is significant variation with female work participation across different industry divisions.

Oni \& Okanlawon (2011) studied transport planning in Nigeria: A plea for incorporating the gender factor and evaluates gender allocation of transport planners/providers/traffic management agencies at the management level in Nigeria and state the need for integrating gender issues into transport planning and policy in Nigeria, the study uses secondary data and various data collected were analyzed using percentage. The study reveals that the proportion of women among transport planners in Nigeria is insignificant and that women are not adequately represented among transport planners/providers and traffic management agencies in Nigeria.

APTA (2011) conducted a research on the economic impact of transportation investment in Nigeria and discovered that transportation generate nearly $\$ 500$ million to the federal, state and local government annually. Tanimowo \& Ibrahim (2013) used primary data, which were obtained through a random systematic sampling of 500 households in Ilorin, Nigeria. Data collected were analyzed using descriptive and inferential statistics. The results showed unprecedented fear that people have for engaging in transport activities. Feeling sad and level of worrisome people subjected to while using transport facilities is also high.

5.1 An Overview of Nigeria Labor-Force

Nigeria is a middle income, mixed economy and emerging market, with expanding financial, service, communication, transportation and entertainment sector. It is the most populous country in Africa and the eighth most populous country in the world (Ngozi, 2010). Despite the large economic role of oil, the informal sector (e.g., transportation and agricultural sector) is the biggest employer in the country, employing over two thirds of the population and accounting for a third of Nigeria's GDP. As of 2007 , about $66 \%$ of the Nigerian population was in the labor force, and the country's population growth rate between 2005 and 2010 is estimated at $2.3 \%$ per annum. Labor force participation in Nigeria for adult women was 38.7\% in 2007, a rise from 38.1\% in 2005 and $37.0 \%$ in 2000 (Ngozi, 2010). For adult men, labor force participation has been declining from $73.7 \%$ in 2000 to $71.7 \%$ in 2005, and then to $70.6 \%$ in 2007. The unemployment rate in Nigeria was at $4.9 \%$ (Ngozi, 2010). According to the National Bureau of Statistics (NBS), the rate of unemployment in Nigeria stood at 23.9 per cent in 2011, while urban unemployment was estimated at 29.5 per cent in 2013 (Chima, 2014). 


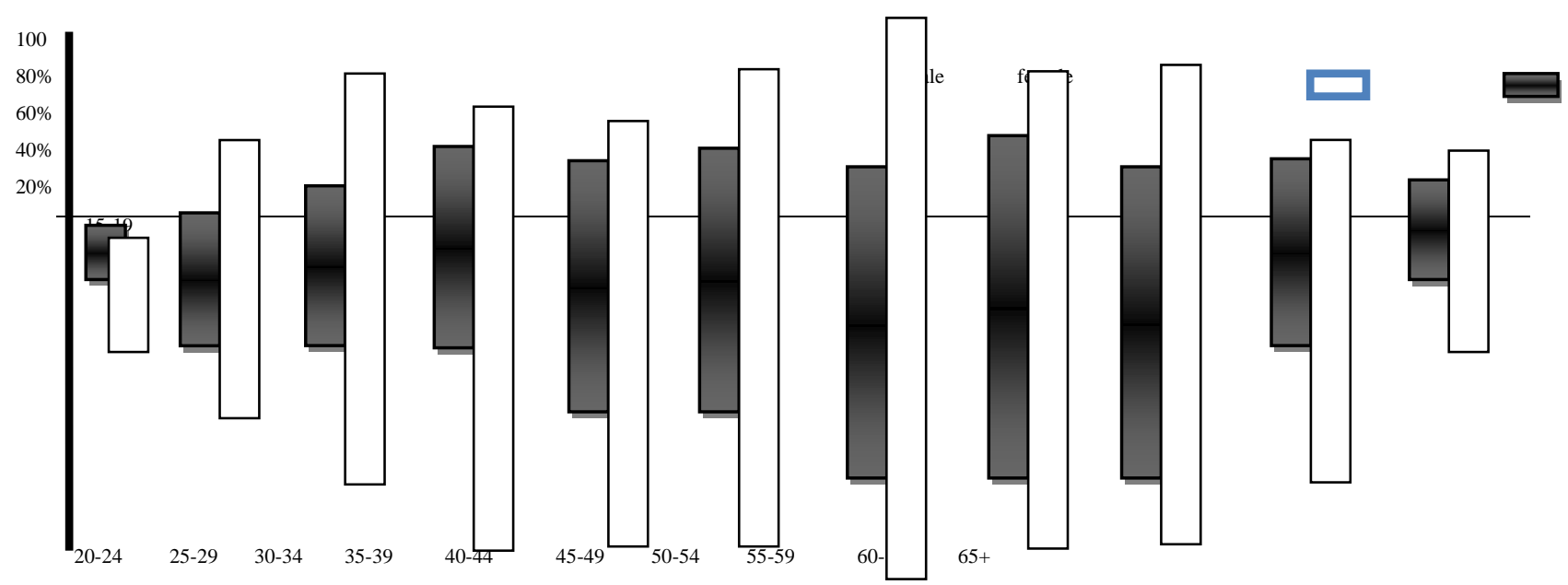

Figure 1: Labour force participation in Nigeria

Source: International Labor Organization (2010)

The figures show a high level of inequality in the workforce. The highest percentage of men in the workforce is among those aged $45-49(99.2 \%)$ compared to just $67 \%$ of their female counterparts. The highest percentage of women in the workforce $(69.5 \%)$ is among those aged 50-54. Naturally in the labor market, one would always see series of labor market behaviors such as demand for labor, supply of labor, job search, incomes and wages, unemployment, wage determination. In Nigeria there are peculiar problems that deter the Nigeria labor market from functioning properly and this problem should be put into consideration. One major problem is the increasing rate of the labor force not marched with a corresponding increase in job opportunities.

5.2 An Overview of Female Labor-Force in Nigeria

By the virtue of the population of Nigeria the potential female labor forces is $50 \%$ but actual value is $31 \%$ (Peter, 2013). The proportion of women in the formal sector is very minimal. This is noticeable in the industries and the civil service, which is the highest employer in the country; women are mostly found in the junior categories.

Women are mainly involved in petty trading, selling wares in the market and street hawking in urban areas. According to statistics $78 \%$ of women are mostly engaged in the formal sector, which are farming and petty trading. Despite this, their contribution is not measure monetarily. The women's unpaid labor is twice that of men, and its economic value is estimated to be up to $30 \%$ of the nation's gross national product (2010).

Women self-advancement has been curtailed by the burden of reproduction, particularly in Nigeria with a very high birth rate as well as cultural roles associated to women- role of child bearing, child care and homemaking. In Nigeria today, women are excluded from certain occupational categories due to formal barriers as well as informal barriers to entry. Few Nigerian women are engaged in top management cadre of formal sector establishments simply because majority of them lack the educational qualifications necessary for such positions Nigeria women face a lot of discrimination that limit their opportunities to develop their full potential on the basis of equality with men (Olukem, 2008). The 1999 constitution forbids discrimination on the basis of sex. Nevertheless, the reality is that Nigerian women are far from enjoying equal rights in the labor market, mainly to their domestic burden, low level of education attainment and discriminatory salaries. The legal protection granted by the constitution and the labor act has little or no effect in the informal sector-agriculture and domestic services where the vast majority of women are employment.

6. Study Area and Methodology

6.1. A Brief History of Lokoja, Kogi State

Kogi state is found in the central region of Nigeria. It is popularly called the confluence state because the influences of river Niger and Benue is at its capital, Lokoja, which is the first administrative capital of modern day Nigeria. Lokoja is also a local government area of Kogi State with an area of $3180 \mathrm{~km}^{2}$ and a population of about 195,261 at the 2006 census (Isah, 2013). It is bounded by the Niger in the north and east upstream from the capital until the border with kwara State, and includes the city of lokoja. Although the area has been inhabited for thousands of years, the present settlement at lokoja was established in 1857 by the British explorer William Baikie. It was in lokoja, that the name Nigeria was coined by Flora Shaw, the wife of Lugard, a British colonial administrator which gazing out at the river that stretched before her in the late $19^{\text {th }}$ century (Isah, 2013). 


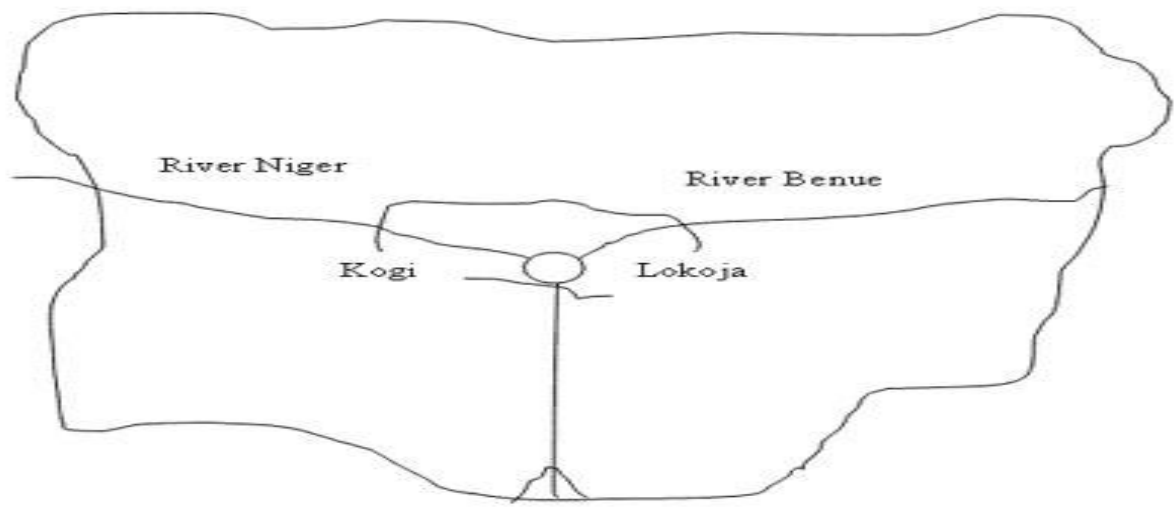

Map of Nigeria showing Lokoja, Kogi state Source: Google.com (n.d.).

The State was created in 1991 from part of kwara State and Benue State. It connects the federal capital territory with 22 southern States, being in close proximity to Abuja, which is the capital of Nigeria.

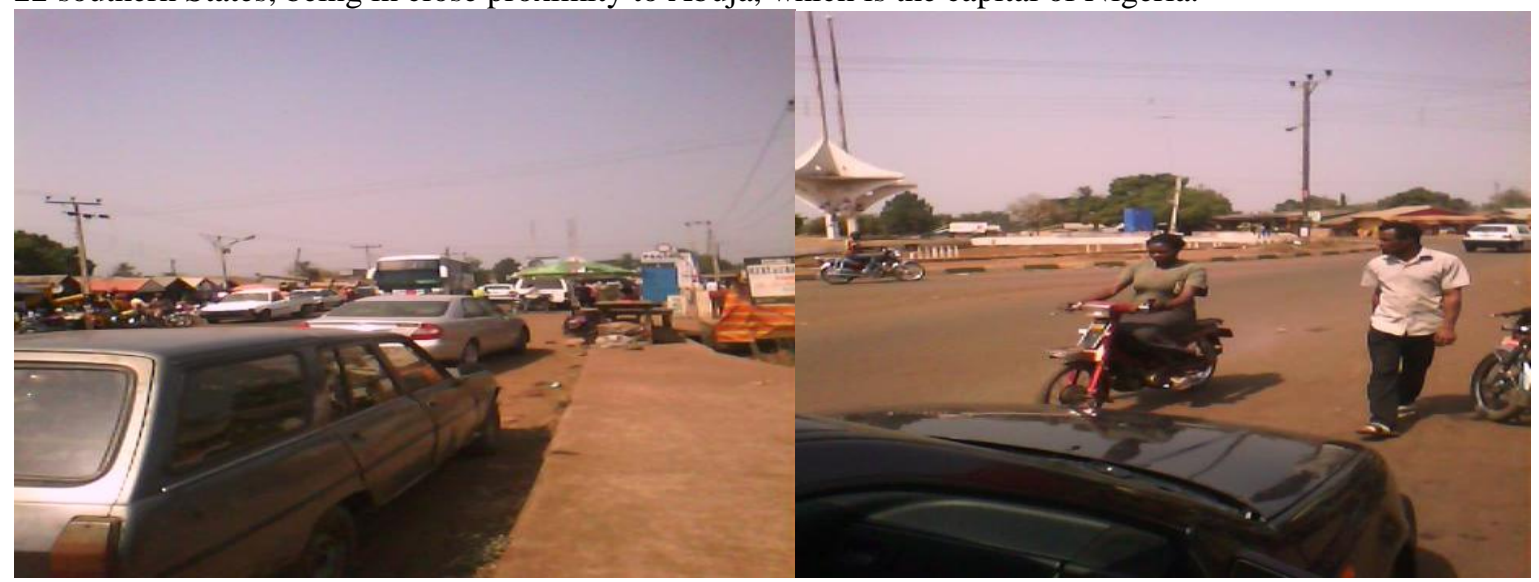

Figure2: Anyigba Motor Vehicle and Motor Cycle park, one hour and thirty minute drive to Lokoja, Kogi State capital.

Source: Photo from field survey 2014

Figure 3:A lady riding a motorcycle in Igala unity square Anyigba.

Source: Photo from field survey 2014

\subsubsection{Research Design}

This study used a cross sectional survey design. The purpose of cross sectional survey design is to obtain detailed data and factual information of an existing phenomenon.

\subsubsection{Population}

The targets in the population of the study are employers, workers, passengers and individual in the transportation sector in Lokoja. These categories of people in the population are large.

6.1.3. Instrumentation

Self-designed questionnaire was specifically used to accomplish the objectives of the study. The questionnaire is divided into two sections. The first section obtained information such as age, sex, marital status, position, occupation and education level the second section contained 16 questions which measured the effect of gender bias in transportation sector.

6.14. Sampling technique

In order to ensure equal representation, simple random sampling method was employed within Lokoja transportation sector which are: road and water transport. Random sampling technique was used to give the sample population an equal chance or probability of being selected. The total number in the selected sample is one hundred and twenty (120), and 102 questionnaires were retrieved. It was distributed in order to have large responses from the respondents, since the population sample is infinite. 


\subsection{Technique of Analysis}

The analysis of data was based on the frequency of the people's perception over issues under investigation and this was determined by a simple percentage representation. In the interpretation, the higher the percentage means the greater the impact or performance of such variable on the subject matter.

For the purpose of interpretation and presentation of such data in an easy form, table and bar chart presentation were used while ANOVA and chi-square distribution was used to test hypothesis.

7. Result and Discussion

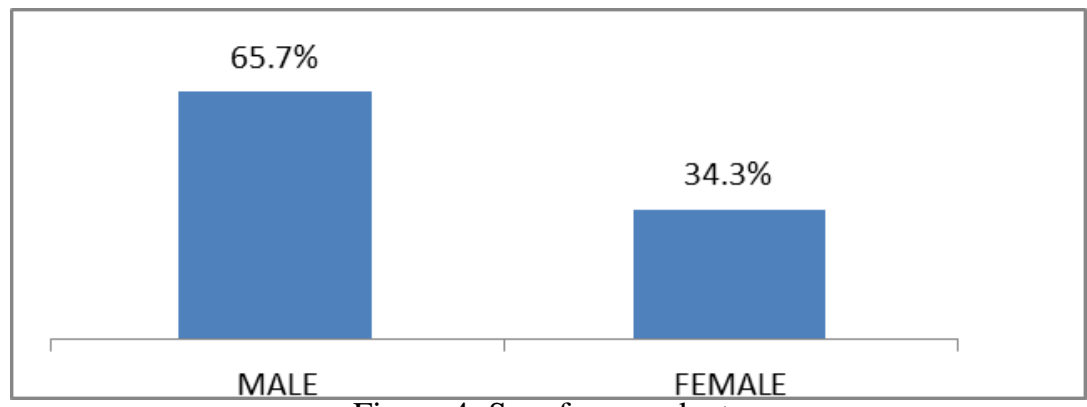

Figure 4: Sexof respondents

Source: Field survey 2014

From bar chart above $65.7 \%$ were male respondents while $34.3 \%$ were female respondents.

Table 1: What is your occupation?

\begin{tabular}{ccc}
\hline Detail & Frequency & Percentage (\%) \\
\hline Driver & 18 & 17.7 \\
\hline Motorcyclist & 22 & 21.6 \\
\hline Sailor & 3 & 2.9 \\
\hline Others & 59 & 57.8 \\
\hline Total & 102 & 100 \\
\hline
\end{tabular}

Source: Field survey.

Table 1 clearly shows that $17.7 \%$ were driver, $21.6 \%$ were motorcyclist, $2.9 \%$ of the respondents were sailor and $57.8 \%$ of the respondents were from other occupation.

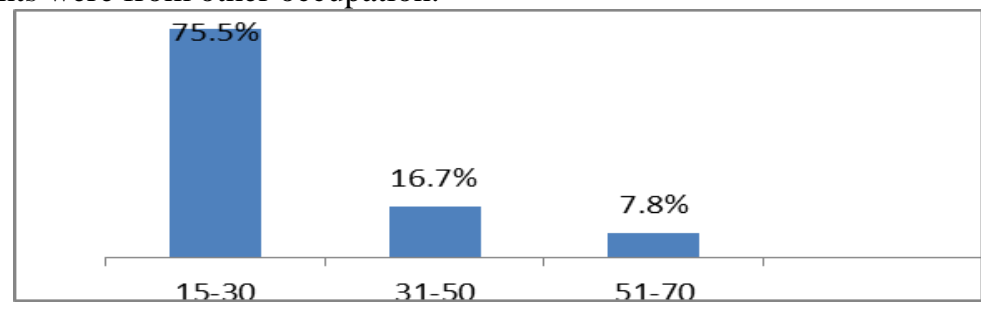

Figure 5: Age of respondents

Source: Field survey.

From the bar chart (Figure 5) above $75.5 \%$ belong to the age group of $15-30$, while $16.7 \%$ belongs to the age group of $31-50$, and $7.8 \%$ belongs to the age group of $51-70$.

Table2: Women are not discriminated based on culture and social norms in the transportation sector.

\begin{tabular}{ccc}
\hline Detail & Frequency & $\begin{array}{c}\text { Percentages } \\
(\boldsymbol{\%})\end{array}$ \\
\hline Agree & 38 & 37.3 \\
\hline Strongly agree & 15 & 14.7 \\
\hline Disagree & 31 & 30.4 \\
\hline Strongly disagree & 18 & 17.6 \\
\hline Total & 102 & 100 \\
\hline
\end{tabular}

Source: Field survey. 
Table 2 depicts that $37.3 \%$ of the population agreed that women are discriminated in the transportation sector based on culture and social norms. This response aligns with Reskin and Roos' (1990) argument which takes account of non-economic factors such as stereotypes, prejudices, custom and peer pressure that lead workers to rank jobs in a certain way, and for example may lead women to deselect themselves for certain typically male jobs. However, table 2 shows that $30.4 \%$ disagree that female are discriminated in the transportation sector based on culture and social norms and $17.6 \%$ of the respondents strongly disagree to the statement.

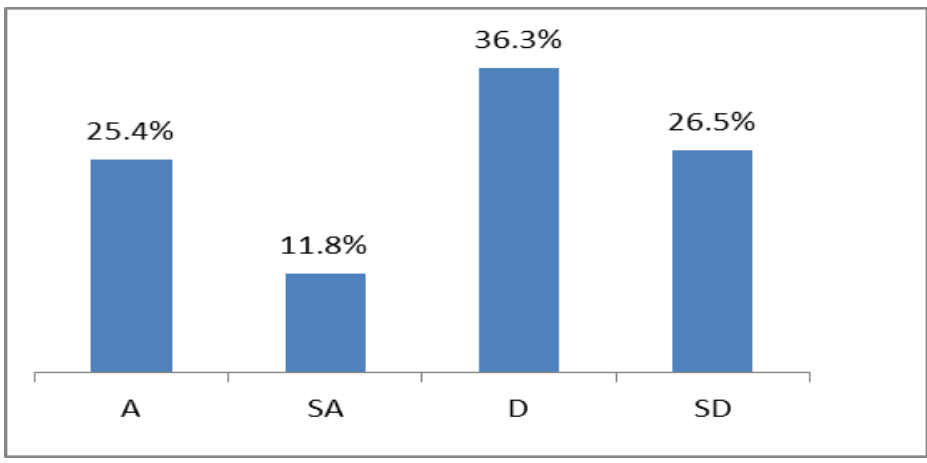

Figure 6: Religion encourages women participation in transportation sector.

Source: Field survey.

From the above bar chart $25.4 \%$ of the respondents agree that religion support women participation in the transportation sector while $11.8 \%$ strongly agree and $36.3 \%$ of the respondent disagree that religion encourages women participation in the transportation sector while $26.5 \%$ strongly disagree. The result accords H'madoun's (2010) bid to examine the influence of religion on female labor force participation across countries, the religious women were found to participate less in labor market activities than the non-religious women.

Table 3: Insecurity is not a constraint faced by women in the transportation sector.

\begin{tabular}{lll}
\hline Detail & Frequency & Percentage (\%) \\
\hline Agree & 23 & 22.5 \\
\hline Strongly agree & 10 & 9.8 \\
\hline Disagree & 38 & 37.3 \\
\hline Strongly disagree & 31 & 30.4 \\
\hline Total & 102 & 100 \\
\hline & Source: Field survey.
\end{tabular}

As can be seen in table 3,22.5\% of the respondents agree that insecurity is not a constraint faced by women in the transportation sector while $9.8 \%$ strongly agree and $37.3 \%$ of the respondents disagree that insecurity is not a constraint faced by women in the transportation sector while $30.4 \%$ strongly disagree. Nonetheless, as Turnbull et al (2013) observe, violence against transport workers is one of the most important factors limiting the attraction of transport jobs for women and breaking the retention of those who are employed in the transport sector.

Table4: Sexual harassment encourages women to engage in transportation sector.

\begin{tabular}{lll}
\hline Detail & Frequency & Percentages\% \\
\hline Agree & 7 & 6.8 \\
\hline Strongly agree & 13 & 12.8 \\
\hline Disagree & 30 & 29.4 \\
\hline Strongly disagree & 52 & 51.0 \\
\hline Total & 102 & 100 \\
\hline
\end{tabular}

Source: Field survey.

Tables 4shows that $6.8 \%$ of the respondents agree that sexual harassment encourages women in the transportation sector while $12.8 \%$ strongly agree and $29.4 \%$ of the respondent disagree that sexual harassment encourages women engagement in the transportation sector while $51.0 \%$ strongly disagree to the statement. This result concurs with Yusuf (1998) that argued that women face discrimination at workplace right from the point of recruitment throughout their work lives. 
Table 5: Employers considered women as inferior and do not fit in the transportation sector.

\begin{tabular}{lll}
\hline Detail & Frequency & Percentage (\%) \\
\hline Agree & 41 & 40.2 \\
\hline Strongly agree & 20 & 19.6 \\
\hline Disagree & 26 & 25.4 \\
\hline Strongly disagree & 15 & 14.7 \\
\hline Total & 102 & 100 \\
\hline
\end{tabular}

Source: Field survey.

From the above table (95), $40.2 \%$ of the respondent agrees that employers see women as inferior and do not fit in transportation sector. This result accords the Equal Opportunity for Women in the Workplace Agency (EOWA) \& Diversity Council (2008) and Auspoll Survey on Pay Equity (2008) which found that women's skills are viewed as "soft or social skills" rather than industrial or workplace skills. On the other hand, $14.7 \%$ of the respondents strongly disagree to the statement that women are seen as inferior in transportation sector.

Table 6: Nursing mothers are employed by bus and truck owner in the transportation sector.

\begin{tabular}{lll}
\hline Detail & Frequency & Percentage (\%) \\
\hline Agree & 27 & 26.5 \\
\hline Strongly agree & 9 & 8.8 \\
\hline Disagree & 31 & 30.3 \\
\hline Strongly disagree & 35 & 34.3 \\
\hline Total & 102 & 100 \\
\hline
\end{tabular}

Source: Field survey.

From the above table (6), $26.5 \%$ of the respondent agree that nursing mother are employed in the transportation sector, $8.82 \%$ strongly agree while $30.3 \%$ of the respondent disagree that nursing mother are employed in the transportation sector, $34.3 \%$ of the respondent strongly disagree with the statement.

Tables 7: Employers do not employ women because they considered them as not having the strength for effective job.

\begin{tabular}{lll}
\hline Detail & Frequency & Percentage (\%) \\
\hline Agree & 34 & 33.3 \\
\hline Strongly agree & 22 & 21.6 \\
\hline Disagree & 31 & 30.4 \\
\hline Strongly agree & 15 & 14.7 \\
\hline Total & 102 & 100 \\
\hline
\end{tabular}

Source: Field survey.

From table 7, above $33.3 \%$ of the respondents agree that employer do not employed women because they considered them as not having the strength for effective job, $21.6 \%$ strongly agree and $30.4 \%$ of the respondents disagree while $14.7 \%$ of the respondents strongly disagree with the statement.

Table 8: Men discourage bus and truck owners from engaging their wives in the transportation sector.

\begin{tabular}{lll}
\hline Detail & Frequency & Percentages (\%) \\
\hline Agree & 43 & 42.2 \\
\hline Strongly agree & 17 & 16.6 \\
\hline Disagree & 27 & 26.5 \\
\hline Strongly disagree & 15 & 14.7 \\
\hline Total & 102 & 100 \\
\hline
\end{tabular}

Source: Field survey .

Table 8 above shows that $42.2 \%$ of the respondents agree that men discourages bus and truck owner from engaging their wives in transportation sectors $16.6 \%$ strongly agree and $26.5 \%$ of the respondents disagree that men discourages bus and truck owner from engaging their wives in the transportation sector, $14.7 \%$ of the respondents strongly disagree. 
Table 9: Employer considered the distance of a journey as a reason for not employing women in the transportation sector

\begin{tabular}{lll}
\hline Detail & Frequency & $\begin{array}{l}\text { Percentages } \\
(\boldsymbol{\%})\end{array}$ \\
\hline Agree & 46 & 45.1 \\
\hline Strongly agree & 22 & 21.6 \\
\hline Disagree & 18 & 17.6 \\
\hline Strongly disagree & 16 & 15.7 \\
\hline Total & 102 & 100 \\
\hline \multicolumn{3}{l}{ Source: Field survey. }
\end{tabular}

Table 9 above it shows that $45.1 \%$ of the respondents agree that employer considered distance of a journey as a reason for not employing women in transportation sector, $21.6 \%$ strongly agree and $17.6 \%$ of the respondents disagree that employer do not considered distance as a reason for not employing women in the transportation sector, $15.7 \%$ of the respondent strongly disagree with the statement.

\subsection{Test of Hypothesis}

To test the null hypothesis that women constraints have no significant effect in transportation sector in Lokoja, the frequency responses from table 2,3,4 and figure 6 were consulted. Analysis data using Chi-square test at 5\% level of significance shows that the value of the calculated $\chi^{2}$ is greater than the critical value, i.e., $43.7>16.919$. Therefore, we reject the null hypothesis and accept the alternative hypothesis that women constraint has significant effect in transportation sector in Lokoja. However, in Lokoja and many places in Nigeria, insecurity, pregnancy, customs, social norms and religion pose great challenges to women in workplace and affect their productivity. Nonetheless, transport business in Lokoja is so dominated by male counterpart and yetsome routes are not adequately covered in terms of conveying passengers. This result is contrary to Odufuwa, Oriola, \&Otubaga (2012) that showed that women constraints have no effect in transportation growth.

8. Conclusion and Recommendation

Transport sector can induce economic growth by increasing job opportunities to march with increasing rate of labour force (especially female). Transport is useful for conveying passenger and goods and it should be more planned with gender issues incorporated in it. The following are therefore recommended based on the findings of this research effort:

Social attitude in Lokoja, Kogi state and Nigeria in general should be changed in favour of women employment in transport sector. To ensure this, strict obedience of gender laws is required which will lead to an increase in the percentage of women participation in transportation institutions.

In this regard, the National Union of Road Transport Worker (NURTW) which is the umbrella body of road transport workers in Nigeria has a strategic part to play by encouraging employment of women in transportation business as well as encouraging them to invest in the sector.

The government of Kogi state should establish driving schools and transport scheme meant to enhance the livelihood of women. This will help women to acquire the driving skill and commercial vehicles to earn a living whether in rural or urban areas.

\section{References}

Adetunji, M. A. (2013). Assessment of the quality of urban transport services in Nigeria:Academic Journal of Interdisciplinary Studies, 2(1),2281-4612.

America Public Transport Association (APTA) (2011). Economic impact of public transportation investment.Retrieved at http://www.apta.com/resourse

Anand, A., and Tiwari, G. (2006). A gendered perspective of the shelter-transport-livelihood link: The Case of Poor Women in Delhi, Transport Reviews, 26(1),63-80.

Asiyanbola, R. A. (2007). Intra -urban transportation, gender and psychological distress in developing countries: Nigeria" Urban Population Development and Environment Dynamics in Developing Countries, OlabisiOnabanjo University, Ago -Iwoye, Ogun State Nigeria, 17(2), 62-72.

Auspoll Research Consulting Pty Ltd(2008).Australians' Attitude to Gender Pay Equity, Australia, pp9 \& 15 . Bivas, C., \&Panigrahi, A. (2013). Gender bias in Indian industry: The Journal of Industrial Statistics, 2(1), 108-127. 
Chima, O. (2014). Nigeria's Unemployment Rate May Rise by 2\%. http://www.thisdaylive.com/articles/nigeria-sunemployment-rate-may-rise-by-2-/168227

Equal Opportunity for Women in the Workplace Agency (EOWA) (2008), Australian Census of Women in Leadership, Research conducted by Macquarie University, p10.

Fernando, P. (2002). Balancing the load: Gender issues in rural transport: London International Forum for Rural Transport and Development (IFRTD). Retrieved from http://www.ifrtd.gn.apc.org.

Google.com (n.d.). Map of Nigeria showing Lokoja, Kogi state.http://www.google.com.ng/imgres?imgurl=http://www.ejpau.media.pl/articles/volume10/issue1/art05-fig-1.jpg\&imgrefurl=http://www.ejpau.media.pl/volume10/issue1/art05.html\&h=341\&w=400\&tbnid=W7c2oubWaJriWM:\&zoom=1\&docid=dEEGQHAKrm2tZM\&ei=o5UJV anZFqvA7AaAqoGADw\&tbm=isch\&ved=0CB8QMygAMAA

H'madoun, M. (2010). 'Religion and labor force participation of women' Faculty of Applied Economics, University of Antwerp. Downloaded from http://www.ua.ac.be/tew

Hanson, S., and Hanson, P. (1980). The impact of women's employment on household t

Travel patterns: A Swedish example. In Women's Travel Issues (S. Rosenbloom, ed,), U.S. Government Printing Office. Washington, D.C.

Haralambos, M., \&Holborn, M. (2007). Sociology themes and perspective: $7^{\text {th }}$ edn, 77-85 Fulham palace road Hammersmith: Harpercollins Publisher Limited.

Hara, O. (2013). Encyclopedia of political economy,2,Routledge. Retrieved from http:// www.britannical.com/EBchecked

Isah, U. (2013). Historical development of Igala land and leadership problem: Anyigba main garage, Dekina L.G.A: Ele-ojo printing studio.

Jhingan, M.L. (2007).Macroeconomic theory: B-5,Ashish complex opp. Ahlco phase-1, delhi-11oo9:Vrinda Publications(p) Limited.

Kamuhanda, R., and Schmidt, O. (2009).Matatu: A case study of the core segment of the public transport market of Kampala, Uganda. Transport Reviews, 29(1)129-142.

Ngozi, O. (2010).The center on aging and work: Nigeria Workforce, 2(13), 022-024.

Odega, D. (2014). Gender disparity, susceptibility and mobility strains coping approaches in Nigeria: African Journal of Geography and Regional Planning, 1(3), 084-088.

Odufuwa, B. (2007). Women participation in household automobile decision making in a developing economyNigeria: Pakistan Journal of Social Sciences, 4(6), 739-745.

Odufuwa, B., Oriole, S., \&Otubaga, O. (2012). Women and the use of public transport in Nigeria traditional city Ibadan: Global Journal of Human Social Science, Art and Humanities, 12(8), 1256.

Ogunsanya, A. (2002). Maker and breakers of children on their parents' travel behaviors: A Comparative Analysis.Transportation Research Record, 1135.Retrieved from http:// www.netplaces.com.

Oladele, J. (2001). The Nigeria economy 'growth productivity and the monetary policy: Development Policy Center, 978-8003-05-02. Retrieved from http \ www.cenbank.org.

Olukem, I. (2008). Female labor force in Nigeria: An International Journal of Sociology of the Family, 21(2), 568.

Oni, S.I., \&Okanlawon, K. R. (2011).Transport planning in Nigeria: A Plea for Incorporating the Gender Factor: $J$ SocSci, 29(2), 177-182.

Oyesiku, O., \&Odufuwa, B. (2002). Gender perspectives in travel behavior of motorcycle passengers in Nigerian intermediate cities: In Xavier Godard and Innocent Fatonzoun (eds.) Urban Mobility for all, Lisse: A. A. Balkema, the Netherlands, 11(1), 112-128.

Peter, T. (2013). Promoting employment of women in the transportation sector: Geneva, 298, 9789221282440. Retrieved from http://www.ilo.org/publns

International Labor Office

Reskin, B., and Roos, P.A. (1990). Job queues, gender queues: Explaining qomen's inroads into male occupations. Philadelphia: Temple University Press.

Rosen bloom, S. (2005). Understanding women's and men's travel patterns: The Research Challenge. In Conference Proceedings 35: Research on Women's Issues in Transportation : Report of a Conference; Volume 2: 
Technical Papers, Transportation Research Board of the National Academies, Washington, D.C ., pp. 413.

Srinivasan, S. (2005). Influence of Residential location on travel behavior of women in Chennai, India. In Conference Proceedings 35; Research on Women's Issues in Transportation : Report of a Conference; Volume 2: Technical Papers, Transportation Research Board of the National Academies, Washington, D.C., pp. 4-13.

Tanimowo, N., B, \& Ibrahim, R.(2013).Differential effects of transportation on Male-Female psychological distress in Ilorin, Nigeria:Global Journal of Human Social Science Arts, Humanities \& Psychology, 13(3),2249$460 x$

Transport Research Board (TRB) (2006). Research on women's issues in transportation:Report of a Conference, 1. Conference Overview and Plenary Papers. $\quad$ November 18th- 20th, 2004, Chicago, Illinois.

Turnbull, P., Lear, J., and Thomas, H. (2013).Women in the transport sector. International Labour Office (ILO), Geneva . TRANSPORT POLICY BRIEF 2013. http://www.ilo.org/wcmsp5/groups/public/--ed_dialogue/---sector/documents/briefingnote/wcms_234882.pdf

World Bank. (2001). Integrating Gender into the World Bank's work: A strategy for action. Retrieved from hppt://www.worldbank.org.

World Bank ( 2010). World Bank indicator-Nigeria-economic activity.Retrieved from http:// www.tradingeconomics.com/Nigeria.

Yusuf, N. (1998). Gender issues in Nigeria's industrial relations. Journal of Arts and Social Science, Department of General Studies, Federal University of Technology, Owerri, 1(1), 81-90.

\section{Copyrights}

Copyright for this article is retained by the author(s), with first publication rights granted to the journal.

This is an open-access article distributed under the terms and conditions of the Creative Commons Attribution license (http://creativecommons.org/licenses/by/4.0/) 